\title{
Hoc volumine continentur
}

\section{Praefatio - 1}

1 De Enarrationum in Psalmos 110-118 tempore et genere -1

2 Libri recensiti -3

3 De codicum cognatione eorumque stemmate -6

3.1 Errores $\alpha-7$

3.2 Errores $\delta \longrightarrow 7$

3.3 Errores hyparchetypi $\pi(=\alpha+\delta)-7$

3.4 Errores $X-7$

3.5 Errores coniunctivi $\pi \chi-8$

3.6 Errores vel falsae lectiones hyparchetypi $\varepsilon-\mathbf{8}$

3.7 Errores coniunctivi $X \varepsilon-\mathbf{8}$

4 De huius editionis ratione -9

\section{Conspectus siglorum -11}

\section{Enarrationum textus -13}

In Psalmum CX 13

In Psalmum CXI -18

In Psalmum CXII -24

In Psalmum CXIII, Sermo I- 30

In Psalmum CXIII, Sermo II -38

In Psalmum CXIV -46

In Psalmum CXV $-\mathbf{5 2}$

In Psalmum CXVI $\mathbf{5 8}$

In Psalmum CXVII $\mathbf{5 8}$

In Psalmum CXVIII, Prooemium - 68

In Psalmum CXVIII, Sermo I- 69

In Psalmum CXVIII, Sermo II - 73

In Psalmum CXVIII, Sermo III -76

In Psalmum CXVIII, Sermo IV - $\mathbf{8 0}$

In Psalmum CXVIII, Sermo V - 84

In Psalmum CXVIII, Sermo VI $-\mathbf{8 7}$

In Psalmum CXVIII, Sermo VII - 91

In Psalmum CXVIII, Sermo VIII - 94

In Psalmum CXVIII, Sermo IX - 100

In Psalmum CXVIII, Sermo X -104

In Psalmum CXVIII, Sermo XI - 108

In Psalmum CXVIII, Sermo XII - 114

In Psalmum CXVIII, Sermo XIII - $\mathbf{1 2 0}$

In Psalmum CXVIII, Sermo XIV -123 
In Psalmum CXVIII, Sermo XV - 127

In Psalmum CXVIII, Sermo XVI - 133

In Psalmum CXVIII, Sermo XVII - 137

In Psalmum CXVIII, Sermo XVIII - 142

In Psalmum CXVIII, Sermo XIX - 147

In Psalmum CXVIII, Sermo XX 151

In Psalmum CXVIII, Sermo XXI - 155

In Psalmum CXVIII, Sermo XXII 159

In Psalmum CXVIII, Sermo XXIII - 165

In Psalmum CXVIII, Sermo XXIV - $\mathbf{1 7 0}$

In Psalmum CXVIII, Sermo XXV - 173

In Psalmum CXVIII, Sermo XXVI - $\mathbf{1 8 0}$

In Psalmum CXVIII, Sermo XXVII - 185

In Psalmum CXVIII, Sermo XXVIII - 189

In Psalmum CXVIII, Sermo XXIX 192

In Psalmum CXVIII, Sermo XXX - 198

In Psalmum CXVIII, Sermo XXXI - 200

In Psalmum CXVIII, Sermo XXXII - 205 